\title{
PEMBINAAN OLIMPIADE MATEMATIKA BAGI SISWA DAN GURU SD DI DESA SAMBANGAN
}

\author{
I Nyoman Gita 1,*, Putu Pasek Suryawan ${ }^{2}$, I Gusti Nyoman Yudi Artawan ${ }^{3}$ \\ 1 Jurusan Pendidikan Matematika. Universitas Pendidikan Ganesha, Indonesia \\ 2 Jurusan Pendidikan Matematika. Universitas Pendidikan Ganesha, Indonesia \\ 3 Jurusan Pendidikan Matematika. Universitas Pendidikan Ganesha, Indonesia
}

\begin{abstract}
Abstrak
Kegiatan pengabdian pada masyarakat ini dilaksanakan dengan tujuan untuk meningkatkan kemampuan siswa dan guru SD No.3 Sambangan dalam menyelesaikan soal-soal olimpiade matematika SD. Kegiatan pengabdian ini dilaksanakan dengan metode berbentuk pelatihan yang dapat mengembangkan daya nalar tingkat tinggi melalui pengerjaan soal-soal olimpiade matematika. Yang terlibat sebagai subyek sasaran dalam kegiatan ini adalah siswa dan guru SD No.3 Sambangan sebanyak 30 orang. Dari kegiatan yang telah dilaksanakan dapat disimpulkan hal-hal sebagai berikut. (1) Seluruh siswa terlihat sangat antusias dalam mengikuti pembinaan. Hal ini dapat dilihat dari keaktivan siswa mengerjakan soal dalam kelompoknya dan semangat siswa untuk menuliskan hasil diskusinya di papan tulis. Demikian juga jika jawaban temannya salah siswa yang lain sangat antusias memberikan masukan. (2) Siswa dapat menyelesaikan soal setelah mendapat pertanyaan pancingan.
\end{abstract}

\author{
Keywords: \\ Olimpiade, matematika.
}

\section{Pendahuluan}

Matematika sebagai salah satu ilmu dasar merupakan mata pelajaran yang wajib diajarkan pada jenjang pendidikan sekolah dasar (SD) maupun sekolah menengah. Menurut Ruseffendi (1992) menyatakan bahwa ada beberapa alasan perlunya siswa belajar matematika adalah: (1) matematika merupakan cara manusia berpikir; (2) matematika sebagai alat dan pelayan ilmu; (3) kegunaan matematika di sekolah; (4) pemakai matematika; (5) nilai-nilai luhur matematika. Pencarian kebenaran dalam matematika disajikan sebagai suatu cara manusia berpikir, sehingga keabsahan dari pemikiran kebenaran tidak diragukan lagi. Demikian juga dalam menyelesaikan persoalan sehari-hari atau persoalan lainnya yang memerlukan matematika sebagai suatu cara yang khusus, misalnya persamaan, pertidaksamaan, model matematika dan sebagainya. Sedangkan dalam menggali informasi untuk disampaikan kepada orang lain sehingga mudah dibaca, mudah dikenal, dan mudah dimengerti, digunakan cara yang khas juga, misalnya dengan berbagai teknik pengumpulan data, pengolahan data, dan penyajian data. Matematika sebagai alat bantu dan pelayan ilmu tidak hanya untuk matematika sendiri tetapi juga untuk ilmu-ilmu lainnya, baik untuk kepentingan teoritis maupun kepentingan praktis sebagai aplikasi dari matematika. Di samping itu matematika juga mengandung nilai-nilai luhur seperti: nilai praktis, nilai disiplin, dan nilai budaya.

Tujuan pembelajaran matematika di sekolah adalah untuk: (1) melatih cara berpikir dan menalar dalam menarik kesimpulan; (2) mengembangkan aktivitas kreatif yang melibatkan imajinasi, intuisi, dan penemuan dengan mengembangkan pemikiran divergen, original, rasa ingin tahu, prediksi dan dugaan serta mencoba-coba; (3) mengembangkan kemampuan pemecahan masalah, dan (4) mengembangkan kemampuan menyampaikan informasi dan mengkomunikasikan gagasan. Walaupun guru sudah tahu ke empat tujuan pembelajaran matematika di sekolah seperti disebutkan di atas namun dalam pembelajaran matematika di SD guru sangat jarang memberikan soal-soal yang dapat mengembangkan kreatif siswa seperti soal -soal uraian terbuka yaitu soal-soal yang mempunyai lebih dari satu jawaban. Contoh: Tentukan ketiga sisi segitiga yang merupakan bilangan bulat dan kelilingnya 15 satuan. Soal -soal yang diberikan guru merupakan soal yang mempunyai jawaban tunggal.

SD Sambangan terletak di Kecamatan Sukasada, Kabupaten Buleleng. Di desa Sambangan terdapat 3 SD. Berdasarkan hasil wawancara dengan Kepala Sekolah SD No.3 Sambangan terkait dengan lomba matematika yang dilaksanakan oleh HMJ Pendidikan Matematika Undiksha siswa-siswanya belum 
pernah mengikuti lomba. Kepala Sekolah belum pernah mengirimkan siswanya dalam lomba matematika karena mereka tidak yakin siswanya bisa mendapat juara. Mereka juga menanyakan di mana mereka bisa mendapatkan soal-soal olimpiade matematika. Mereka mengharapkan Undiksha mengadakan pengabdian kepada mereka mengenai pengayaan materi matematika khususnya yang menyangkut materi olimpiade matematika. Mereka sangat sulit mendapatkan soal-soal olimpiade. Untuk membuat soal-soal semacam soal olimpiade juga sangat sulit. Selama ini soal-soal yang diberikan kepada siswanya adalah soal-soal yang mirip di buku paket. Jenis soal semacam itu bisa dikatagorikan soal rutin yaitu soal yang dalam penyelesaiannya lebih mengutamakan keterampilan dan kurang dapat mengembangkan daya nalar siswa. Soal-soal sejenis soal olimpiade biasanya diselesaikan dengan cara tidak biasa (luar biasa). Untuk menyelesaikan soal-soal sejenis soal olimpiade

\section{Metode}

Tujuan yang diangkat dalam kegiatan pengabdian pada masyarakat ini adalah meningkatkan kemampuan siswa dan guru SD di desa Sambangan dalam memahami konsep matematika dan meningkatkan kemapuan guru SD di desa Sambangan dalam membuat soal-soal matematika yang dapat mengembangkan daya nalar siswa dalam rangka mengikuti olimpiade matematika. Oleh karena itu, kerangka pemecahan masalah secara operasional sebagai berikut: a) Menetapkan jumlah peserta pembinaan yaitu dengan melibatkan siswa kelas IV dan V SD No.3 Sambangan dan guru yang mengajar matematika di kelas tersebut. b) Memberikan materi pembinaan tentang olimpiade matematika tingkat SD. c) Memberi kesempatan kepada guru untuk membuat soal matematika yang dapat mengembangkan daya nalar tingkat tinggi dari siswa.

Kegiatan pengabdian masyarakat yang dilakukan menggunakan metode berbentuk pelatihan yang dapat mengembangkan daya nalar tingkat tinggi melalui pengerjaan soal-soal olimpiade matematika melalui tahapan sebagai berikut. 1) Seminggu sebelum pelaksanaan pelatihan, guru diberikan soal-soal olimpiade matematika yang dilengkapi dengan pembahasan. 2) Pada saat pelatihan guru memberikan soal-soal olimpiade matematika kepada siswa secara bersama-sama dengan tim palaksana pengabdian. 3) Siswa mengerjakan soal-soal olimpiade matematika secara berkelompokdilakukan ketiga hal berikut sekaligus yaitu tekun, paham konsep dan mampu berpikir kreatif. Sebagai contoh untuk tingkat SD adalah : Diketahui tiga bidang yaitu segitiga samasisi, persegi dan lingkaran yang mempunyai keliling yang sama. Bidang yang mana yang mempunyai luas daerah paling besar. Untuk menjawab itu siswa harus tahu konsep keliling, konsep luas daerah dari ketiga bidang tersebut dan mampu menghubungkan antara bidang yang satu dengan yang lainnya. Dari persoalan di atas maka dipandang perlu diadakan P2M untuk mengatasi persoalan tersebut. Pelaksanaan P2M kali ini dilaksanakan pembinaan olimpiade matematika bagi siswa dan guru SD di Desa Sambangan. Melalui pembinaan olimpiade matematika bagi siswa dan guru SD di Desa Sambangan, siswa dan guru-guru akan lebih mampu mengembangkan materi matematika sehingga lebih berani mengirimkan siswa-siswanya dalam berbagai lomba matematika. Tujuan yang diangkat dalam kegiatan pengabdian pada masyarakat ini adalah meningkatkan kemampuan siswa dan guru SD di desa Sambangan dalam memahami konsep matematika dan meningkatkan kemapuan guru SD di desa Sambangan dalam membuat soal-soal matematika yang dapat mengembangkan daya nalar siswa dalam rangka mengikuti olimpiade matematika. Oleh karena itu, kerangka pemecahan masalah secara operasional sebagai berikut. Menetapkan jumlah peserta pembinaan yaitu dengan melibatkan siswa kelas IV dan V SD No.3 Sambangan dan guru yang mengajar matematika di kelas tersebut. Memberikan materi pembinaan tentang olimpiade matematika tingkat SD.

Memberi kesempatan kepada guru untuk membuat soal matematika yang dapat mengembangkan daya nalar tingkat tinggi dari siswa Kegiatan pengabdian masyarakat yang dilakukan menggunakan metode berbentuk pelatihan yang dapat mengembangkan daya nalar tingkat tinggi melalui pengerjaan soal-soal olimpiade matematika melalui tahapan sebagai berikut. Seminggu sebelum pelaksanaan pelatihan, guru diberikan soal-soal olimpiade matematika yang dilengkapi dengan pembahasan Pada saat pelatihan guru memberikan soal-soal olimpiade matematika kepada siswa secara bersama-sama dengan tim palaksana pengabdian. Siswa mengerjakan soal-soal olimpiade matematika secara berkelompok. Untuk melaksanakan kegiatan tersebut digunakan beberapa metode pelatihan, yaitu: a. Metode Ceramah

Metode ceramah digunakan pada pertemuan pertama untuk menjelaskan apa itu olimpiade dan strategi yang digunakan untuk menyelesaikan soalsoal olimpiade matematika. Metode Tanya jawab sangat penting bagi peserta pelatihan untuk menanyakan hal-hal yang belum dipahami dan mengemukakan pendapatnya tentang jawaban yang dikemukakan oleh temannya. Setelah siswa menyelesaikan soal-soal olimpiade matematika secara berkelompok, selanjutnya salah satu temannya menuliskan hasil pekerjaannya di papan tulis. Selanjutnya teman-temannya memberi komentar tentang 
apa yang dituliskan di papan tulis. Jika ada kesalahan maka guru atau tim pengabdian menggiring siswa agar memperoleh jawaban yang benar.

Untuk melihat keberhasilan pelaksanaan kegiatan perlu diadakan evaluasi. Evaluasi yang digunakan dalam kegiatan ini adalah sebagai berikut. 1) Evaluasi proses, dilakukan pada saat kegiatan dilaksanakan. Aspek yang di evaluasi adalah aktivitas peserta dalam mengikuti pelatihan. Keberhasilan dapat dilihat dari aktivitasnya selama kegiatan baik bertanya, menjawab pertanyaan dan diskusi. 2) Evaluasi Hasil, dilaksanakan setelah berakhirnya kegiatan yaitu dengan melihat partisipasi siswa dalam lomba matematika yang dilaksanakan oleh Jurusan Pendidikan Matematika FMIPA Undiksha, dinas pendidikan, maupun instansi lain yang mengadakan lomba matematika.

\section{Hasil Dan Pembahasan}

Pembinaan olimpiade matematika di SD No.3 Sambangan, kecamatan Sukasada diberikan oleh instruktur dari tim pelaksana yaitu I Nyoman Gita, Putu Pasek Suryawan dan Gusti Nyoman Yudi Artawan. Pada pertemuan pertama tim pengabdian secara bergantian memberikan penjelasan tentang apa itu olimpiade, apa yang harus dilakukan agar dapat mengerjakan soal-soal olimpiade matematika dengan benar. Selanjutnya siswa dibagikan soal-soal olimpiade matematika untuk dikerjakan secara berkelompok. Selama mengerjakan soal-soal olimpiade matematika, siswa dibantu oleh guru dan tim pengabdian masyarakat dari Undiksha. Soal yang diberikan pada pertamuan pertama sebanyak 48 soal namun yang dikerjakan hanya sepuluh soal sedangkan soal selebihnya dibahas pada pertemuanpertemuan selanjutnya oleh guru dan didampingi oleh tim pengamdian. Setelah siswa selesai mengerjakan soal, beberapa wakil kelompok disuruh menerangkan ke papan tulis. Setiap selesai mengerjakan satu soal di papan tulis kelompok yang lain disuruh memberi tanggapan. Jika terjadi kesalahan maka instruktur dari tim pengabdian menggiring siswa dengan pertanyaan-pertanyaan yang dapat menyadarkan siswa bahwa yang dikerjakannya salah. Pertanyaan- pertanyaan pancingan diberikan sampai siswa dapat menyelesaikan soal yang diberikan. Pada pertemuan selanjutnya pembinaan matematika diberikan oleh guru dan didampingi oleh tim pengabdian Undiksha. Setiap pertemuan antara tim pengabdian Undiksha dengan geru SD No.3 Sambangan selalu didiskusikan tentang kesulitankesulitan yang dialami siswa dalam mengerjakan soal-soal olimpiade matematika maupun kesulitan dari guru dalam membina siswa dalam menyelesaikan soal-soal olimpiade matematika.

Pada awal pertemuan pertama semua kelompok mengalami kesulitan dalam mengerjakan soalsoal olimpiade matematika karena mereka belum biasa mengerjakan soal-soal di luar buku paket dan diluar LKS. Tetapi mereka tampak senang dan bersemangat untuk mengerjakannya. Siswa mengerjakan soal-soal olimpiade secara berkelompok. Tim pengabdian dari Undiksha mengarahkan siswa untuk mengerjakan soal secara berrurutan mulai dari nomor satu. Setelah semua kelompok selesaikan menyelesaikan sola nomor satu, selanjutnya secara acak satu kelompok disuruh ke depan untuk mempresentasikan hasil pekerjaannya. Sedangkan kelompok lain memberikan tanggapan. Selama satu kelompok presentasi di depan kelas kelompok yang lain tidak boleh mengerjakan soal yang lainnya. Jadi semua kelompok fokus memperhatikan penyelesaian soal nomor satu. Sedangkan kelompok yang lain memberikan tanggapan atau perytanyaan jika da yang kurang jelas. Jika terjadi kesalahan maka tim pengamdian dari Undiksha menggiring siswa agar menyadari kesalahan yang dilakukan. Selanjutnya terus digiring dengan pertanyaan-pertanyaan sampai siswa dapat menyelesaikan soal nomor satu dengan benar. Demikian juga untuk soal nomor dua, tiga, empat dan seterusnya dilakukan dengan hal yang identik dengan penyelesaian soal nomor satu. Untuk soal nomor 4 beberapa kelomopok dengan cepat menjawab dua bilangan yang jumlahnya 17 dan selisihnya sama dengan 5. Dengan memberikan pertanyaan pancingan ahirnya semua kelompok menjawab dengan benar. Pada hari pertama soal yang dapat diselesaikan hanya sepuluh soal. Untuk soal selebihnya dilakukan pembinaan oleh guru dan didampingi oleh tim pengabdian dari Undiksha.

\section{Simpulan Dan Saran}

Berdasarkan hasil evaluasi terhadap pelaksanaan kegiatan pengabdian yang dilaksanakan maka dapat disimpulkan sebagai berikut. a) Seluruh siswa terlihat sangat antusias dalam mengikuti pembinaan. Hal ini dapat dilihat dari kreaktifnya siswa mengerjakan soal dalam kelompoknya dan semangat siswa untuk menuliskan hasil diskusinya di papan tulis. Demikian juga jika jawaban temannya salah siswa yang lain sangat antusias memberikan masukan. B) Siswa dapat menyelesaikan soal setelah mendapat pertanyaan pancingan. Berdasarkan respon yang diberikan oleh siswa dan berdasarkan diskusi dengan guru 
maka kegiatan perlu dilaksanakan secara kontinu agar siswa dapat mengikuti olimpiade matematika minimal lolos di tingkat kecamatan.

Melalui kesempatan ini, kami mengucapkan terima kasih setulus-tulusnya kepada pihak-pihak berikut. LPPM Undiksha yang telah memfasilitasi kami dalam menyediakan dana sehingga kegiatan ini dapat terlaksana dengan baik. Kepala SD No.3 Sambangan yang telah memberikan fasilitas tempat untuk pelaksanaan kegiatan ini. Guru dan siswa SD No.3 Sambangan yang telah berpartisipasi dalam kegiatan ini. d. Semua pihak yang tidak dapat disebutkan satu persatu yang juga telah mendukung kegiatan pengabdian ini.

\section{Daftar Pustaka}

Ahmad Muchlis, Dkk. 2006. Buku Referensi Maju Dengan Olimpiade Matematika Untuk SD, Jakarta : Karya Duta Wahana Bambang Susianto. 2004. Olimpiade Matematika Dengan Proses Berpikir Aljabar dan Bilangan. Jakarta : Grasindo

Nikenasih Binatari. 2007. Super Geneus Olompiade Matematika SD. Yogyakarta : Pustaka Widyatama

Ruseffendi, E. T. 1992. Pendidikan Matematika 3. Jakarta: Departemen Pendidikan dan Kebudayaan.

Suwah Sembiring. 2004. Olimpide Matematika Untuk SMU. Bandung : Yrama Widya. 